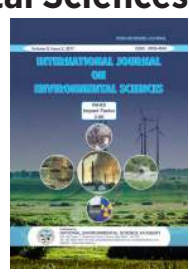

\title{
GROUNDWATER QUALITY ASSESSMENT FOR DRINKING PURPOSE IN BADHRA BLOCK, CHARKHI DADRI DISTRICT, HARYANA, INDIA
}

\author{
Anup Kumar ${ }^{1}$, Himanshu and V.S. Arya ${ }^{2}$ \\ ${ }^{1}$ Front Office-HARSAC, Panchkula, Haryana, India \\ ${ }^{2}$ Deptt. of Geology, Kurukshetra University, Kurukshetra, Haryana, India \\ ${ }^{3}$ Haryana Space Applications Centre (HARSAC), Hisar, Haryana, India
}

Research Article

Received: 15.04.2020

Accepted: 22.04.2020

Published: 05.05.2020

\begin{abstract}
Water is important for survival of living beings and non-living developmental activities. In the present developmental scenario requirement of water is increasing very fast. In arid to semi-arid regions groundwater is very important for fulfilling the need of people. Badhra block is falling in Charkhi Dadri district of Haryana state, India. The climate of the block is semi-arid. Groundwater is the main source for drinking and irrigation purpose. In the study area ten groundwater samples were collected in the month of January, 2019. Groundwater samples were analyzed using field water testing kit prepared by Tamilnadu Water Supply and Drainage Board, Chennai for twelve chemical parameters-pH, alkalinity, hardness, chloride, total dissolved solids, fluoride, iron, nitrite, nitrate, ammonia, phosphate and residual chlorine. In the groundwater samples $\mathrm{pH}$ varies from 7 to 7.5 , alkalinity $250-450 \mathrm{mg} / \mathrm{l}$,hardness $70-580 \mathrm{mg} / \mathrm{l}$,chloride $60-600 \mathrm{mg} / \mathrm{l}$, total dissolved solids (TDS) 564-1704 mg/l, fluoride $0.5-3 \mathrm{mg} / \mathrm{l}$, iron nil in all groundwater samples, ammonia nil to $1 \mathrm{mg} / \mathrm{l}$, nitrite $0.2-0.5 \mathrm{mg} / \mathrm{l}$, nitrate $45-75 \mathrm{mg} / \mathrm{l}$, phosphate nil to $0.5 \mathrm{mg} / \mathrm{l}$, residual chlorine nil in all ten groundwater samples. Groundwater is potable in one sample taken at Dalawas and non-potable in nine groundwater samples taken at Lad (fluoride $2 \mathrm{mg} / \mathrm{l}$, ammonia 1mg/l, nitrate 75mg/l), Badhara (fluoride 3mg/l), Kari (nitrate 75mg/l), Sisrli (nitrate 75mg/l), Dandma (nitrate $75 \mathrm{mg} / \mathrm{l}$ ), Jeoli (nitrite $75 \mathrm{mg} / \mathrm{l}$ ), Mandi (nitrate $75 \mathrm{mg} / \mathrm{l}$ ), Rahrodi (nitrate 75mg/l), Dohka (nitrate $75 \mathrm{mg} / \mathrm{l})$. The study is highly useful for monitoring of groundwater quality for drinking purpose.
\end{abstract}

Keywords: Assessment, groundwater, potable, non-potable, Badhra, Charkhi Dadri, Haryana.

\section{INTRODUCTION}

Water is important for survival of living beings on the planet Earth. Besides requirement for living beings, other activities like agriculture and industry are also dependent on water. In arid to semi-arid regions groundwater is very important because of less availability of surface water. Groundwater quality plays vital role in its use for various purposes. Drinking water for human consumption should be as per drinking water standards to avoid health problems. But in the present context of developmental activities availability of good quality groundwater is very less. Many workers have studied groundwater quality in different types of terrain conditions (Hussainand Prasad Rao (2013), Prasad et al. (2014), Moghaddam et al (2018), VijayaLalithaand Sai Tejaswini (2017), Chaudhary et al. (2015), Perween and Fatima (2015), Rani and Chaudhary (2015), Celestino et al. (2018)).

*Corresponding author: anup0106@yahoo.com 


\section{STUDYAREA}

Badhra block is located in Charkhi Dadri district of Haryana state, India. Geologically the block has blown sand of recent age. Aeolian plain and sand dunes are geomorphologic features found in the block. The climate of the block is semi-arid type.

\section{OBJECTIVE}

The main objective was to study groundwater quality for drinking purpose in the study area.

\section{MATERIALS AND METHODOLOGY}

In the study are ten groundwater samples were collected in plastic double capped bottles in the month of January 2019. All the ten groundwater samples were analyzed using field water testing kit prepared by
Tamilnadu Water Supply and Drainage Board, Chennai for twelve chemical parameters-pH, alkalinity, hardness, chloride, total dissolved solids, fluoride, iron, nitrite, nitrate, phosphate and residual chlorine. Results of chemical analysis were compared with BIS drinking water standards (IS 10500:2012) to know potable and non-potable of groundwater samples. The chemical analysis data were entered in Excel software and prepared bar graphs of each chemical parameter.

\section{RESULTS AND DISCUSSION}

Chemical analysis results of groundwater samples are given in table 1, BIS drinking water standards in table 2 and graphical representation of results in fig. 1 to fig.12.

Table1: Results of chemical analysis of groundwater samples.

\begin{tabular}{|c|c|c|c|c|c|c|c|c|c|c|c|c|c|c|}
\hline Location & Latitude & Longi- & pH & $\begin{array}{c}\text { Alkali } \\
\text { nity } \\
(\mathrm{mg} /)\end{array}$ & $\begin{array}{c}\text { Hard } \\
\text { ness } \\
(\mathrm{mg} /)\end{array}$ & $\begin{array}{c}\text { Chlo } \\
\text { (mg/) }\end{array}$ & $\begin{array}{c}\text { TDS } \\
(\mathrm{mg} / \mathrm{l})\end{array}$ & $\begin{array}{c}\text { Fluo } \\
\text { ride } \\
(\mathrm{mg} /)\end{array}$ & $\begin{array}{c}\text { Iron } \\
(\mathrm{mg} / \mathrm{l})\end{array}$ & $\begin{array}{c}\text { Amm } \\
\text { onia } \\
(\mathrm{mg} /)\end{array}$ & $\begin{array}{c}\text { Nit } \\
\text { rite } \\
(\mathrm{mg} /)\end{array}$ & $\begin{array}{c}\text { Nit } \\
\text { rite } \\
(\mathrm{mg} /)\end{array}$ & $\begin{array}{l}\text { Phos } \\
\text { phate } \\
\text { (mg/) }\end{array}$ & $\begin{array}{c}\text { Resi } \\
\text { dual } \\
\text { Chlo } \\
\text { rine } \\
(\mathrm{mg} /)\end{array}$ \\
\hline Lad & $28^{\circ} 28^{\prime} 52^{\prime \prime}$ & $75^{\circ} 54^{\prime 2} 23^{\prime \prime}$ & 7.5 & 390 & 100 & 90 & 696 & 2 & 0 & 1 & 0.5 & 75 & 0 & 0 \\
\hline Badhara & $28^{\circ} 31^{\prime \prime} 3^{\prime \prime}$ & $75^{\circ} 55^{\prime} 33^{\prime \prime}$ & 7.5 & 450 & 70 & 200 & 864 & 3 & 0 & 0.5 & 0.2 & 45 & 0 & 0 \\
\hline Kari & $28^{\circ} 31^{\prime} 32^{\prime \prime}$ & $75^{\circ} 54^{\prime} 51^{\prime \prime}$ & 7.5 & 450 & 100 & 180 & 876 & 1.5 & 0 & 0.5 & 0.5 & 75 & 0 & 0 \\
\hline Sisrli & $28^{\circ} 33^{\prime} 41^{\prime \prime}$ & $75^{\circ} 52^{\prime} 55^{\prime \prime}$ & 7.5 & 450 & 330 & 400 & 1416 & 1 & 0 & 0.5 & 0.5 & 75 & 0 & 0 \\
\hline Dandma & $28^{\circ} 34^{\prime} 42^{\prime \prime}$ & $75^{\circ} 53^{\prime} 47^{\prime \prime}$ & 7.5 & 370 & 580 & 470 & 1704 & 1 & 0 & 0.5 & 0.5 & 75 & 0 & 0 \\
\hline Jeoli & $28^{\circ} 31^{\prime} 33^{\prime \prime}$ & $75^{\circ} 57^{\prime} 31^{\prime \prime}$ & 7 & 250 & 150 & 130 & 636 & 0.5 & 0 & 0 & 0.5 & 75 & 0.5 & 0 \\
\hline Dalawas & $28^{\circ} 32^{\prime} 16^{\prime \prime}$ & $75^{\circ} 59^{\prime} 15^{\prime \prime}$ & 7 & 340 & 190 & 140 & 804 & 1 & 0 & 0.5 & 0.2 & 45 & 0 & 0 \\
\hline Mandi & $28^{\circ} 32^{\prime} 41^{\prime \prime}$ & $76^{\circ} 1^{\prime} 27^{\prime \prime}$ & 7.5 & 280 & 150 & 100 & 636 & 1.5 & 0 & 0.5 & 0.5 & 75 & 0 & 0 \\
\hline Rahrodi & $28^{\circ} 33^{\prime} 29^{\prime \prime}$ & $76^{\circ} 3^{\prime 2} 2^{\prime \prime}$ & 7 & 270 & 140 & 60 & 564 & 1 & 0 & 0.5 & 0.5 & 75 & 0 & 0 \\
\hline Dohka & $28^{\circ} 36^{\prime} 49^{\prime \prime}$ & $76^{\circ} 4^{\prime} 41^{\prime \prime}$ & 7.5 & 310 & 370 & 600 & 1536 & 0.5 & 0 & 0.5 & 0.5 & 75 & 0 & 0 \\
\hline
\end{tabular}

Table 2: Drinking water standards (IS 10500:2012)

\begin{tabular}{|l|l|c|c|c|}
\hline S. No. & Parameter & \multicolumn{2}{|c|}{ Potable } & Non-Potable \\
\hline & & Desirable & Permissible & \\
\hline 1 & $\mathrm{pH}$ & 6.5 to 8.5 & - & $<6.5$ to $>8.5$ \\
\hline 2 & Total Hardness (mg/l) & $<200$ & $200-600$ & $>600$ \\
\hline 3 & Iron (mg/l) & $<0.3$ & - & $>0.3$ \\
\hline 4 & Chloride (mg/l) & $<250$ & $250-1000$ & $>1000$ \\
\hline 5 & Total Dissolved Solids (mg/l) & $<500$ & $500-2000$ & $>2000$ \\
\hline 6 & Nitrate (mg/l) & $<45$ & - & $>45$ \\
\hline 7 & Nitrite (mg/l) & $<1.0$ & $1.0-1.5$ & $>1.0$ \\
\hline 8 & Fluoride (mg/l) & $<1.0$ & - & $>1.5$ \\
\hline 9 & Phosphate (mg/l) & $<1.0$ & $0.2-1$ & $>1.0$ \\
\hline 10 & Residual Chlorine (mg/l) & $<0.2$ & - & $>0.5$ \\
\hline 11 & Ammonia (mg/l) & $<0.5$ & $200-600$ & $>600$ \\
\hline 12 & Alkalinity (mg/l) & $<200$ & & \\
\hline
\end{tabular}


I. pH: In the study area $\mathrm{pH}$ varies 7-7.5 in all ten groundwater samples. $\mathrm{pH}$ is desirable (6.5-8.5) in all ten groundwater samples (Table 1, Table 2 and Fig.1).

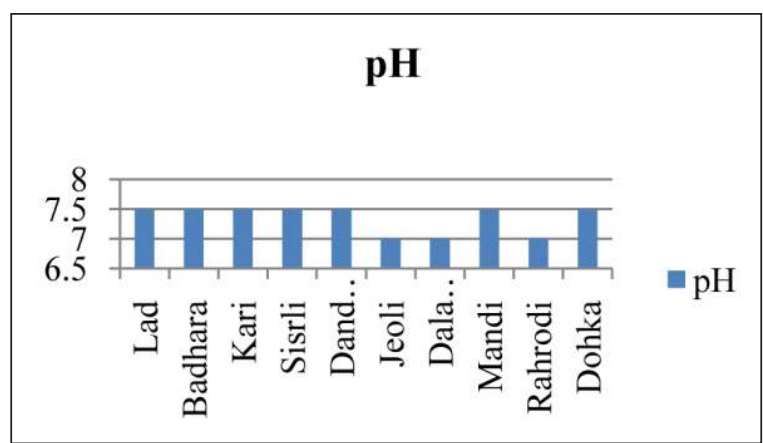

Fig.1: pH in groundwater samples.

ii. Alkalinity:In the study are alkalinity varies 250-450 $\mathrm{mg} / \mathrm{l}$ in all ten groundwater samples. Alkalinity is permissible (200-600 mg/l) in all ten groundwater samples(Table 1, Table 2 and Fig.2).

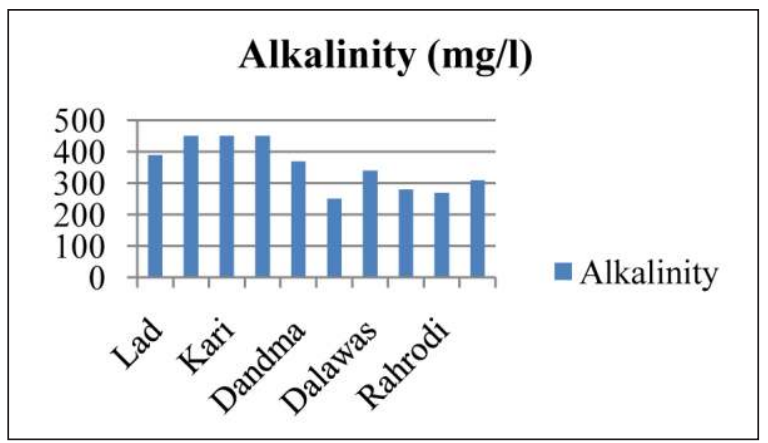

Fig.2: Alkalinity in groundwater samples.

iii. Hardness: In the study area hardness varies 70 - 580 $\mathrm{mg} / \mathrm{l}$ in all ten groundwater samples. Hardness is desirable (<200 mg/l) in seven groundwater samples and permissible (200-600 mg/l) in three groundwater samples (Table 1, Table 2 and Fig.3).

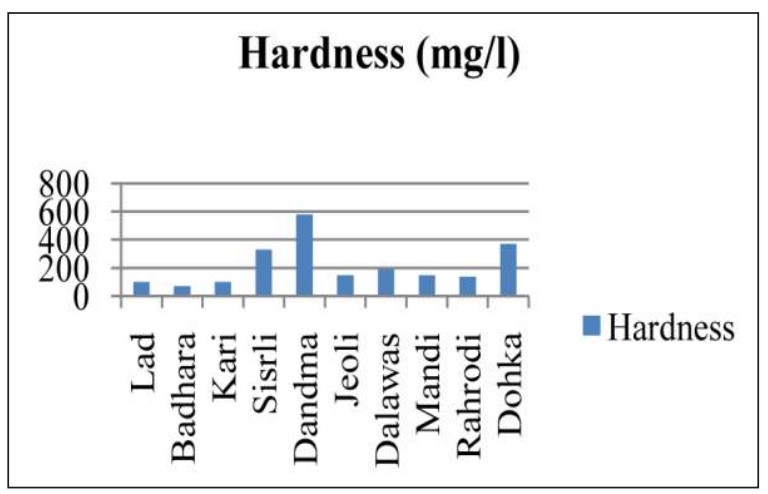

Fig.3: Hardness in groundwater samples. iv. Chloride: Chloride varies $60-600 \mathrm{mg} / \mathrm{l}$ in all ten groundwater samples in the study area. In seven groundwater samples chloride is desirable $(<250 \mathrm{mg} / \mathrm{l})$ and in three groundwater samples permissible (2501000 mg/l) (Table 1, Table 2 and Fig.4).

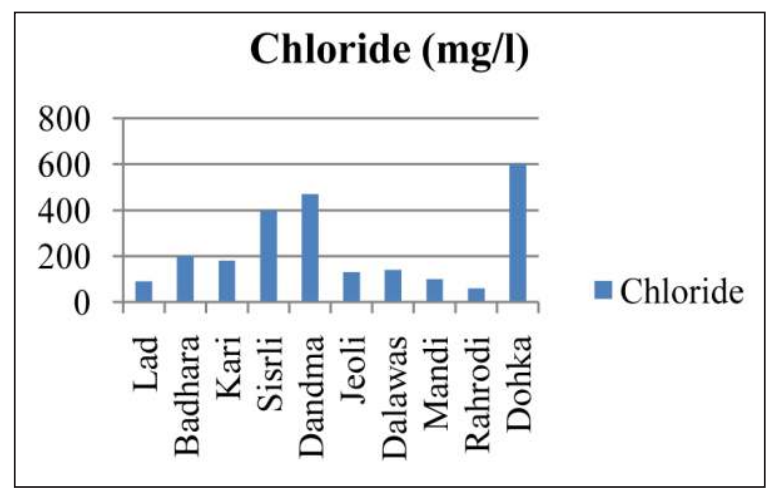

Fig. 4: Chloride in groundwater samples.

v. Total Dissolved Solids: Total dissolved solids (TDS) varies $564-1704 \mathrm{mg} / \mathrm{l}$ in all ten groundwater samples. TDS is permissible (500-2000 mg/l) in all ten groundwater samples in the study area (Table 1, Table 2 and Fig.5).

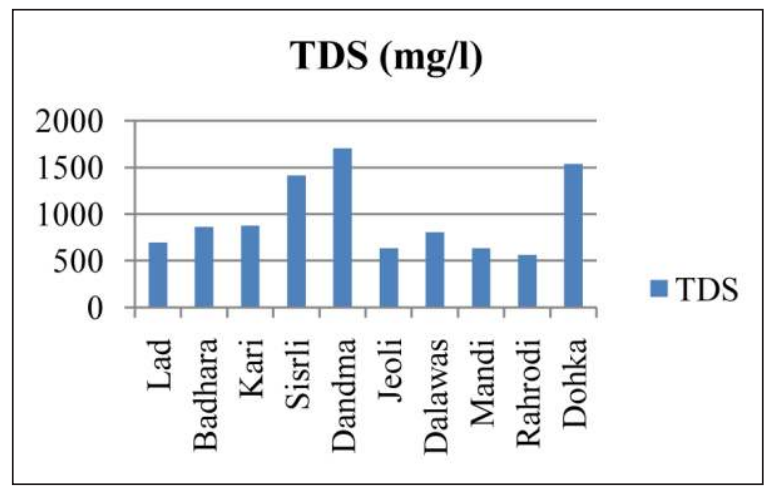

Fig. 5: Total dissolved solids (TDS) in groundwater samples

vi. Fluoride: In the study area fluoride varies 0.5-3 $\mathrm{mg} / \mathrm{l}$ in all ten groundwater samples. Fluoride is desirable $(<1 \mathrm{mg} / \mathrm{l})$ in six groundwater samples, permissible (1-1.5 mg/l) in two groundwater samples and non-potable $(>1.5 \mathrm{mg} / \mathrm{l})$ in two groundwater samples (Table 1, Table 2 and Fig.6).

vii. Iron: In the study area iron is nil in all ten groundwater samples, hence, iron is desirable $(<0.3$ $\mathrm{mg} / \mathrm{l}$ ) in all ten groundwater samples (Table 1, Table 2 and Fig.7). 


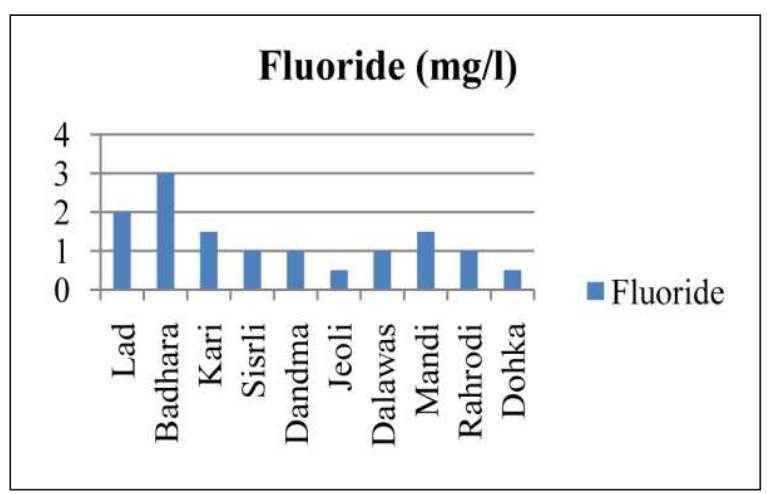

Fig.6: Fluoride in groundwater samples.

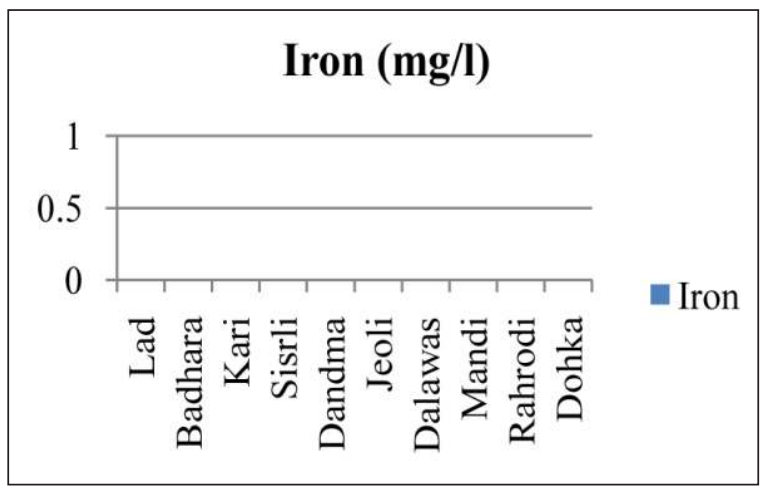

Fig.7: Iron in groundwater samples.

viii. Ammonia: Ammonia varies nil to $1 \mathrm{mg} / \mathrm{l}$ in all ten groundwater samples in the study area. Ammonia is desirable $(<0.5 \mathrm{mg} / \mathrm{l})$ in nine groundwater samples and non-potable $(>0.5 \mathrm{mg} / \mathrm{l})$ in one groundwater sample (Table 1, Table 2 and Fig.8).

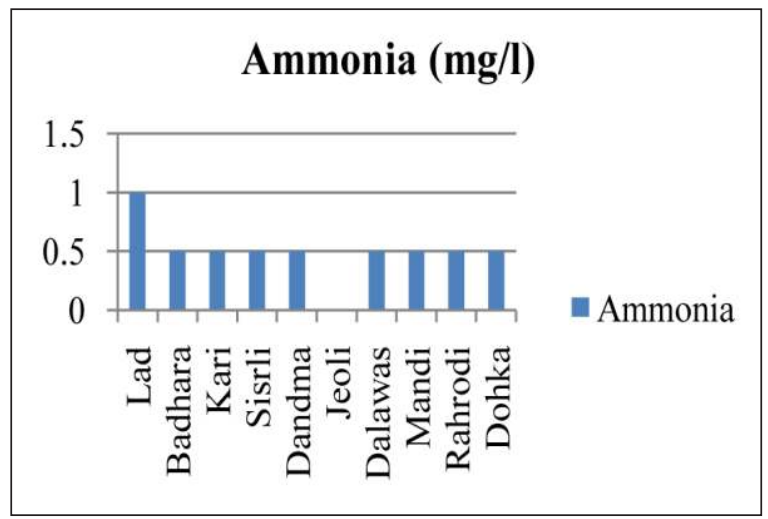

Fig. 8: Ammonia in groundwater samples.

ix. Nitrite: In the study area nitrite varies $0.2-0.5 \mathrm{mg} / \mathrm{l}$ in all ten groundwater samples. Nitrite is desirable $(<1 \mathrm{mg} / \mathrm{l})$ in all ten groundwater samples (Table 1 , Table 2 and Fig.9).

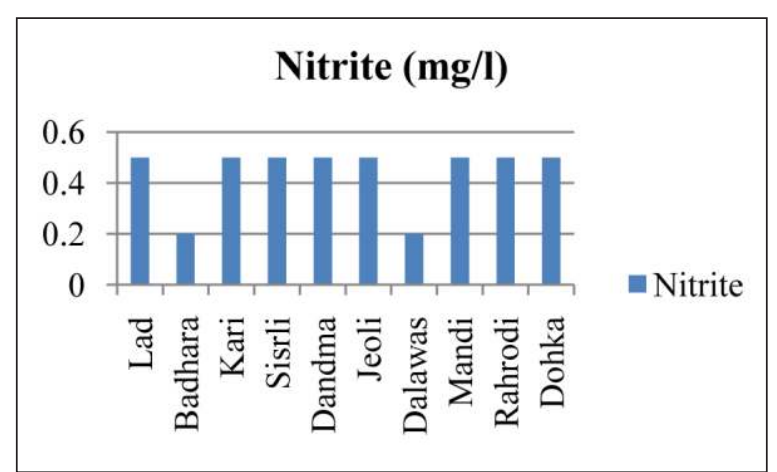

Fig. 9: Nitrite in groundwater samples.

x. Nitrate: In the study area nitrate varies $45-75 \mathrm{mg} / \mathrm{l}$ in all ten groundwater samples. Nitrate is desirable $(<45 \mathrm{mg} / \mathrm{l})$ in two groundwater samples and nonpotable $(>45 \mathrm{mg} / \mathrm{l})$ in eight groundwater samples (Table 1, Table 2 and Fig.10).

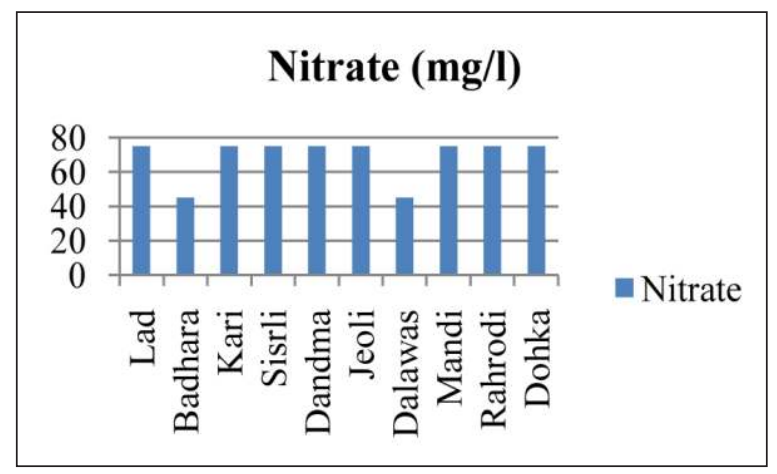

Fig.10: Nitrate in groundwater samples.

xi. Phosphate: In the study area phosphate varies nil to $0.5 \mathrm{mg} / \mathrm{l}$ in all ten groundwater samples. Phosphate is desirable ( $<1 \mathrm{mg} / \mathrm{l})$ in all ten groundwater samples in the study area (Table 1, Table 2 and Fig.11).

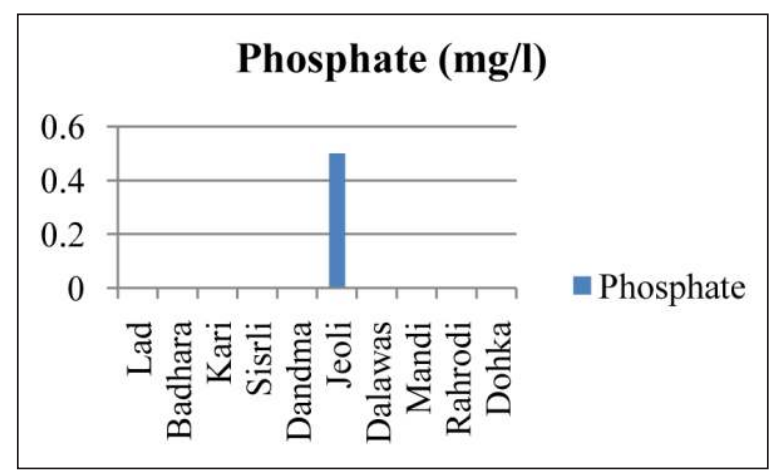

Fig.11: Phosphate in groundwater samples 


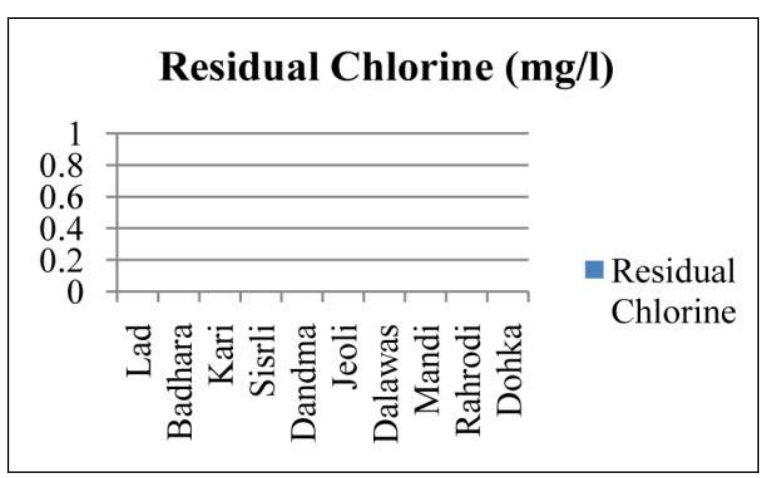

Fig.12: Residual Chlorine in groundwater samples.

xii. Residual Chlorine: Residual chlorine is nil in all ten groundwater samples in the study area, hence, residual chlorine is desirable $(<0.2 \mathrm{mg} / \mathrm{l})$ in all ten groundwater samples (Table 1, Table 2 and Fig.12).

\section{CONCLUSIONS}

Groundwater is potable in one groundwater sample taken at Dalawas and non-potable in nine groundwater samples taken at Lad (fluoride $2 \mathrm{mg} / \mathrm{l}$, ammonia $1 \mathrm{mg} / \mathrm{l}$, nitrate $75 \mathrm{mg} / \mathrm{l}$ ), Badhara (fluoride $3 \mathrm{mg} / \mathrm{l}$ ), Kari (nitrate $75 \mathrm{mg} / \mathrm{l}$ ), Sisrli (nitrate $75 \mathrm{mg} / \mathrm{l}$ ), Dandma (nitrate $75 \mathrm{mg} / \mathrm{l}$ ), Jeoli (nitrite $75 \mathrm{mg} / \mathrm{l}$ ), Mandi (nitrate 75 mg/l), Rahrodi (nitrate 75 mg/l), Dohka (nitrate 75 $\mathrm{mg} / \mathrm{l})$. The study is highly useful for planning and monitoring of groundwater quality for drinking purpose in the study area.

\section{REFERENCES}

1. Celestino, Ana Elizabeth Marin, Cruz, Diego Armando Martinez, Sanchez, Elena Maria Otazo, Reyes, Francisco Gavi, and Soto, David Vasquez (2018). Groundwater quality assessment: an improved approach to K-Means clustering, principal component analysis and spatial analysis: acase study. Water, 10, 437:1-21.

2. Chaudhary, Priyanka, Shukla, Kalawati and Kumar, Jitendra (2015). Status of physicochemical parameter of ground water of Gorakhpur City, U.P. (India), International Journal of
Scientific \& Technology Research, 4 (12):233237.

3. Hussain, Mushtaq and Prasad Rao, T. V. D.(2013). Assessment of the ground water quality and its suitability for drinking andirrigation purposes:a case study of Patancheru, Andhra Pradesh, India. Archives of Applied Science Research, 5 (6):232-238.

4. Moghaddam, Alireza, Moteallemi, Asiyeh, Joulaei, Fatemeh, Peirovi, Roya (2018).A spatial variation study of groundwater quality parameters in the Gonabad Plain using deterministic and geostatistical models, Desalination and Water Treatment,103: 261-269.

5. Perween, Shahida and Fatima, Ummatul (2015).Study of groundwater quality by the assessment of physico-chemicalparameters and water quality index in Aligarh, Uttar Pradesh, Journal of Chemical and Pharmaceutical Research, 7(5):761-771.

6. Prasad, M., Muralidhara Reddy, B., Ramakrishna Reddy, M. and Sunitha, V. (2014). Studies on physicochemical parameters to assess the water quality in Obulavaripalli Mandal of YSR (Kadapa) District, Andhra Pradesh, India, International Journal of Current Research and Academic Review, 2(12): 31-41.

7. Rani, ReetaandChaudhary, B. S. (2015).Spatial distribution mapping and assessment of suitability of groundwater quality for drinking purpose in Hisar District of Haryana State, India, International Journal of Geo Science and Geo Informatics, 2(1):1-8.

8. Vijaya Lalitha, B. and Sai Tejaswini, K. (2017).A study on assessment of groundwater quality and its suitability for drinking in Vuyyuru, Krishna(dist.), Andhra Pradesh, International Journal of Engineering Development and Research, 5(2):1662-1668. 